
\title{
is Research Soure \\ Therapeutic Potential of Salvia Bucharica for Dyslipidemia and Vascular Dysfunction Induced through Two Different Pathways
}

\author{
Muhammad Ishfaq Ahmad \\ University of Sargodha \\ Alamgeer ( $\nabla$ alam_yuchi@yahoo.com ) \\ University of the Punjab \\ Hira Asif \\ The University of Lahore \\ Hafiz Muhammad Irfan \\ University of Sargodha \\ Nasser Hadal Alotaibi \\ Al-Jouf University \\ Khalid Saad Alharbi \\ Al-Jouf University \\ Syed Nasir Abbas Bukhari \\ Al-Jouf University
}

Research

Keywords: Hyperlipidemia, Salvia bucharica, vasorelaxation, toxicity study

Posted Date: June 9th, 2020

DOl: https://doi.org/10.21203/rs.3.rs-31453/v1

License: (1) (1) This work is licensed under a Creative Commons Attribution 4.0 International License. Read Full License 


\section{Abstract}

Background: The present study was endeavored to validate the antihyperlipidemic potential of Salvia bucharica (Lamiaceae) in lipofundin induced hyperlipidemia in rabbits and fructose treated hyperlipidemic rats.

Method: Extract of Salvia bucharica and atorvastation $(10 \mathrm{mg} / \mathrm{kg})$ were given to the animals through oral route. At the end of study period, blood samples were taken for determination of lipid profile. Furthermore, thoracic aorta and liver were studied for vasorexalation and histopathological changes respectively.

Results: Salvia bucharica has shown dose dependent antihyperlipidemic activity with a significant $(\mathrm{p}<0.05)$ decrease in the levels of total cholesterol, low density lipoprotein and triglycerides in both models. In addition, Studies performed on the isolated thoracic aorta and histolopathological studies on liver demonstrated that Salvia bucharica has endothelial dependent vasoprotective and hepatoprotective activity respectively as compared to fructose fed rats. The toxicity studies of Salvia bucharica revealed that plant extract is safer for oral use.

Conclusion Hence, it was suggested that Salvia bucharica has the therapeutic potential against dyslipidemia and vascular dysfunction.

\section{Background}

Hyperlipidemia is a pathological condition that is characterized by elevation in total cholesterol, rise in LDL cholesterol, increase in triglycerides or decrease HDL cholesterol concentration or combination of these abnormalities [1]. Hyperlipidemia is the key risk factor for cardiovascular disorders (CVDs) which has been reported as the foremost cause of death in developed as well as developing nations [2]. Now a days it is considered that CVDs will turn out to be the most common cause of death and disability around the world by the year 2020 [3]. An increasing body of evidence suggested that oxidative stress is involved in the pathogenesis of many cardiovascular diseases, including hypercholesterolemia, atherosclerosis, and hypertension, diabetes, and heart failure [4].

Hyperlipidemia in general is often associated with endothelial dysfunction which is characterized by reduced vascular relaxation governed by limited NO production. Etiology of oxidative stress induced hyperlipidemia involves reactive oxygen species (ROS). ROS are involved in the oxidation of LDL and oxidized LDL is considered to be a contributor to endothelial dysfunction because it inhibits endothelial NO synthase. It is an independent menace to atherosclerosis which can lead to coronary heart disease and ischemic stroke $[4,5]$. Commonly hyperlipidemia is treated with lipid-lowering drugs which are associated with a high risk of side effects such as liver damage, gastrointestinal problems, rhabdomylosis and myopathy. So there is a need of alternative treatment with little adverse effects. The use of plant based medicines has been increasing gradually world-wide in recent years [6] . WHO has recommended the use of indigenous plants as an alternative remedy especially in developing countries. Various medicinal products of herbal origin have been reported to have antihyperlipidemic and antihypercholesteremic properties [2]. 
So the present study was designed to evaluate the antihyperlipidemic effect of Salvia bucharica (Family: Lamiaceae) which is an aromatic plant that grows in Afghanistan, Pakistan and central Asia [7]. Salvia bucharica commonly known as Gul-e-Kakar or Sursanda, widely distributed in Baluchistan, Pakistan. The whole plant is soaked in water and the decoction is used for colic pain, kidney pain, jaundice, malaria fever and high blood pressure [8], but the reports on antihyperlipidemic activity are not present. Therefore this study is performed to investigate effects of Salvia bucharica in dyslipidemia and vascular dysfunction using two different animal models.

\section{Material And Methods}

\section{Chemicals and reagents used}

Atorvastatin (Medipak pharmaceutical industry Pvt. Ltd Lahore), Lipofundin (B Braun Melsungen AG Germany), Diphenylpicrylhydrazyl (DPPH) (Merck Germany), Ascorbic acid (Sigma-aldrich Germany), DFructose, Acetylcholine, Phenylephrine, Potassium chloride, Ketamine chloride and Sodium phenobarbital (Sigma, St. Louis, USA) were used to carry out experimentation.

\section{Selection, collection and authentication of the plant}

The plant for this study was selected based upon its traditional repute in various diseases like kidney pain, jaundice particularly in cardiovascular diseases. The aerial parts of Salvia bucharica were collected in the month of April and May 2015 from Harboi, Nichara District Kalat, Baluchistan Pakistan. The plant was authenticated by Dr. Muhammad Amin Ullah Shah, Department of Botany, University of Sargodha. For further references the voucher specimen (SB-16-23) of plant was deposited in College of Pharmacy, University of Sargodha.

\section{Preparation of Aqueous methanol extract}

The aerial parts of Salvia bucharica were dried under shade at room temperature and grounded into a coarse powder. Aqueous methanol (30:70) extract of the plant was prepared using cold maceration process. After 3 days, it was filtered through muslin cloth, the filtrate was collected, and the plant material was again soaked for 3 days, twice. At the end, all of three filtrates were combined, filtered through muslin cloth and Whatmann qualitative Grade 1 filter paper. The filtrate of the extract was evaporated under reduced pressure in rotary evaporator at $50^{\circ} \mathrm{C}$. This aqueous methanol (30:70) extract was then air-dried to obtain a solid mass $[9,10]$.

\section{Experimental animals used}

A local breed of rabbits weighing 1-2 kg, adult Sprague dawlley rats $(200-250 \mathrm{~g})$ of both sex and mice (25$35 \mathrm{~g}$ ) were procured from local market. Animals were kept under standard environmental conditions (room temperature $22 \pm 2^{\circ} \mathrm{C}$, relative humidity $50 \pm 5 \%$ and $12 \mathrm{~h}$ light and dark cycle) in animal resource center, University of Sargodha. Diet and water were provided ad libitum. Experiments were performed in accordance with guidelines for care and use of laboratory animals provided by the National Research council [11]. The experimental protocols were approved from Institutional Animal Ethics Committee, College of Pharmacy, University of Sargodha (Approval No. 43A24 IEC UOS). 


\section{Pharmacological studies performed on plant extract}

\section{Evaluation of Anti-hyperlipidemic effect of aqueous methanol extract of Salvia bucharica against Lipofundin induced dyslipidemia}

Lipofundin cause rise in lipid profile thus this experiment was conducted to demarcate effect of Salvia bucharica on lipofundin lipid abnormalities. For this purpose, Rabbits weighing 1-2 kg were divided into different groups $(n=5)$. Group I (Normal control) received normal diet and water ad libitum for 23 days, Group II (negative control) received lipofundin $(2 \mathrm{~mL} / \mathrm{kg}$ i.v) for 8 consecutive days then from 9-23th day normal diet and water were given, Group III (positive control), Group IV (SB250) and group V (SB500) initially received lipofundin ( $2 \mathrm{~mL} / \mathrm{kg}$ i.v) for 8 consecutive days then from 9-23th day atorvastatin ( $10 \mathrm{mg} / \mathrm{kg} \mathrm{p.o})$, Salvia bucharica aqueous methanol extract $250 \mathrm{mg}$ and $500 \mathrm{mg}$ p.o, administered respectively. Blood samples of animals were drawn on $8^{\text {th }}$ and $23^{\text {th }}$ day through jugular vein of the rabbits. Blood samples were allowed to clot for $20-25 \mathrm{~min}$ and centrifuged at $2500 \mathrm{~g}$ at $4^{\circ} \mathrm{C}$ for $10 \mathrm{~min}$. Serum was collected and aliquots were stored at $-70^{\circ} \mathrm{C}$ until biochemical analysis [6].

\section{Biochemical parameters measured}

Total cholesterol (TC), Triglyceride (TG), high density lipoprotein cholesterol (HDL-C) levels were measured through laboratory testing from the diagnostic laboratory of University Medical and Diagnostic Center of University of Sargodha. VLDL level, Low density lipoprotein (LDL-C), Atherogenic index (AI) and Coronary risk index (CRI) level were assessed by following formulas

$$
\begin{aligned}
& \mathrm{VLDL}=\mathrm{TG} / 5 \\
& \mathrm{LDL}=\mathrm{TC}-(\mathrm{HDL}+\mathrm{VLDL}) \\
& \mathrm{Al}=\mathrm{TC}-\mathrm{HDL} / \mathrm{HDL} \\
& \mathrm{CRI}=\mathrm{TC} / \mathrm{HDL}[12-14]
\end{aligned}
$$

\section{Effect of Salvia bucharica aqueous methanol extract on Fructose induced hyperlipidemia in rats}

The purpose of this experiment was to investigate the beneficial effect of Salvia bucharica on dyslipidemia induced by chronic administration of fructose. Wister albino rats of both sex weighing $100-150 \mathrm{~g}$ were divided into five following groups: Group I (normal control) received normal diet and water ad libitum for 28 days, Group II (negative control) received fructose $(25 \% \mathrm{w} / \mathrm{v})$ in drinking water and normal diet for 28 days, Group III (positive control) received fructose $\left(25 \% \mathrm{w} / \mathrm{v}\right.$ ) for consecutive 14 days then from $15-28^{\text {th }}$ day atorvastatin (10 $\mathrm{mg} / \mathrm{kg} \mathrm{p.o}$ ) was administered along with fructose $(25 \% \mathrm{w} / \mathrm{v})$. Group IV and V (treatment groups) received fructose $(25 \% \mathrm{w} / \mathrm{v})$ for consecutive 14 days then from $15-28^{\text {th }}$ day plant extract ( 250 and $500 \mathrm{mg}$ p.o) was administered along with fructose $(25 \% \mathrm{w} / \mathrm{v})$. On $29^{\text {th }}$ day animals were sacrificed to collect the blood samples and were kept $30 \mathrm{~min}$ for coagulation, centrifuged at 3000rpm to get serum and the lipid profile was determined [15]. Aortas of animals were removed to determine the vascular reactivity and liver was dissected for histopathological study [16]. 
Total cholesterol (TC), Triglyceride (TG), high density lipoprotein cholesterol (HDL-C) levels were measured through laboratory testing. VLDL level, Low density lipoprotein (LDL-C), Atherogenic index (Al) and Coronary risk index (CRI) level were assessed by above mentioned formulas [12-14].

\section{Evaluation of protective effect of Salvia bucharica on fructose induced vascular dysfunction in rats}

As chronic administration of fructose lead to progression of endothelial dysfunction therefore, this study was designed to assess protective effect of Salvia bucharica on vascular reactivity. Vascular reactivity was performed to observe the functional integrity of endothelium. Rats were killed by cervical dislocation and dissected .The thoracic aorta was separated and placed in the cold Kreb's solution of the following composition (mM): $\mathrm{NaCl} 118, \mathrm{KCl} 4.73, \mathrm{KH}_{2} \mathrm{PO}_{4} 1.2, \mathrm{MgSO}_{4} .7 \mathrm{H}_{2} \mathrm{O} 1.2, \mathrm{CaCl}_{2} 2.5, \mathrm{NaHCO}_{3} 25$, glucose 11 and EDTA 0.026 for 30 seconds. Blood present in the aorta was removed by gently pressing aorta and transferred the aorta to the kreb's solution having temperature $37^{\circ} \mathrm{C}$. Aorta was separated from the surrounding connective tissue and cut into rings of $3 \mathrm{~mm}$ long. Special care was taken to avoid any damage to endothelium. Rings were then mounted in organ-baths by means of two stainless steel wires attached with force-displacement transducer. A resting tension of $2 \mathrm{~g}$ was applied to facilitate the measurement of isometric force. The organ chamber was filled with $10 \mathrm{~mL}$ of Krebs-Henseleit solution at $37^{\circ} \mathrm{C}$ and gassed with $95 \% \mathrm{O}_{2}$ and $5 \% \mathrm{CO}_{2}$. Preparations were allowed to equilibrate for approximately $1 \mathrm{~h}$ with an exchange of Kreb's solution every 15 min. Following $1 \mathrm{~h}$ equilibration the active muscle tone of ring segments contraction was then observed by potassium chloride $(70-80 \mathrm{mM})$ and washout was given by changing the Kreb's solution to return back to its initial tension and allowed to stabilize it for $30 \mathrm{~min}$. Phenylephrine $\left(10^{-6} \mathrm{M}\right)$ was added in the chamber and contraction was noticed and washout period was given by changing the Kreb's solution and allowed to stabilize it at its baseline tension. Again phenylephrine $\left(10^{-6} \mathrm{M}\right)$ was added in the chamber and contraction was observed. After a stable contraction plateau was reached, relaxation of the aortic rings was measured in response to cumulative additions of acetylcholine (Ach; $10^{-9}$ to $\left.10^{-4} \mathrm{M}\right)$ [16-19].

\section{Histopathological examination of liver in fructose treated rats}

On $28^{\text {th }}$ day of treatment in fructose induced hyperlipidemia, rats were sacrificed, liver was dissected and washed with normal saline solution in order to clear it from blood and preserved in $10 \%$ formalin solution. Fixed liver was sectioned (5 micron thickness), embedded in paraffin and sections stained with Hematoxylin and Eosin (H\&E). For estimation of histopathological changes in liver tissues was observed under light microscope $[20,21]$.

\section{Toxicity profile}

Acute toxicity studies performed in present work

This study was performed as per Organization for Economic Cooperation and Development (OECD) guidelines 425 [22].

Study was performed in three phases as following

\section{Phase 1}


Mice were randomly divided into four groups of two mice per group. Graded doses (500, 1000, 1500, 2000 $\mathrm{mg} / \mathrm{kg}$ ) of the Salvia bucharica was administered to the mice orally. After treatment, Mice were continuously observed during next $24 \mathrm{~h}(0.25,0.5,1,2,4,12 \mathrm{~h})$ for mortality, behavioral changes (restlessness, dullness, agitation, sedation) and signs of toxicity.

\section{Phase 2}

After 24 hours based on the findings of phase 1 , three groups of mice $(n=2)$ were given the next doses $(2500$, $3000,3500 \mathrm{mg} / \mathrm{kg}$ ) of Salvia bucharica orally. All the animals were continuously observed for general behavioral changes, symptoms of toxicity and mortality during 24 initially after every 15 min, then every 30 min, then after $1,2,4$ and $12 \mathrm{~h}$.

\section{Phase 3}

After 24 hours, based on the observations of phase 2, Two groups of mice $(n=2)$ were given the next higher doses $(4000,5000 \mathrm{mg} / \mathrm{kg})$ of Salvia bucharica orally. Mice were observed for $24 \mathrm{~h}$ post-treatment for mortality, behavioral changes (restlessness, dullness, agitation, sedation) and signs of toxicity [23].

\section{$\mathrm{LD}_{50}$ determination}

Based on the findings of the acute toxicity study, the lowest dose that killed one mice and the maximum dose that had not killed any mice was recorded. The geographic mean of these doses gave the LD 50 of the Salvia bucharica aqueous methanol extract [23].

\section{Sub-acute Toxicity Test}

Sub-acute toxicity study was performed as per the OECD guidelines 407 (OECD, 2008) with slight modifications. On the bases of findings of acute toxicity test, $1 / 5^{\text {th }}$ of the highest dose of acute toxicity study protocol of Salvia bucharica extract was selected and administered orally on daily basis for 14 days to a group of mice $(n=6)$. Control group of mice $(n=6)$ was received only vehicle for the same duration. All the experimental animals were observed after treatment daily for any abnormal clinical signs and mortality for 14 days. At the end of 14 day's observation period, body weight of mice was measured. The mice were anaesthetized, dissected and their blood samples were collected immediately through cardiac puncture with and without anticoagulant (EDTA), for hematological and biochemical studies respectively[24] . Heart, liver and kidneys of each mouse were individually weighed [25].

\section{Determination of anti-oxidant activity}

Free radical scavenging by use of DPPH (1,1-Diphenyl-2-picryl hydrazyl) radical

DPPH radical scavenging capacity of aqueous methanol extract Salvia bucharica was determined according to the method of Brand- Williams modified by Miliauskas [26] DPPH radicals have an absorption maximum at $515 \mathrm{~nm}$, which disappears with reduction by an antioxidant compound. DPPH solution $\left(6 \times 10^{-5} \mathrm{M}\right)$ in methanol was prepared, and $3 \mathrm{~mL}$ of this solution was mixed with $100 \mu \mathrm{L}$ of each methanol solutions of salvia bucharica extracts and standard solution of Ascorbic acid. Sample and the standard Ascorbic acid 
solution were incubated for $20 \mathrm{~min}$ at $37^{\circ} \mathrm{C}$ in a water bath, and then decrease in absorbance at $515 \mathrm{~nm}$ was measured (AE). A blank sample containing $100 \mu \mathrm{L}$ of methanol in the DPPH solution was prepared, and its absorbance was also measured (AB). The experiment was carried out in triplicate. Radical scavenging activity was calculated using the following formula:

$$
(\% \text { inhibition })=[(A B-A E) / A B] \times 100
$$

Where $A B$ absorbance of the blank sample, and $A E$ absorbance of the plant extract [27].

\section{Phytochemical analysis of Salvia bucharica}

Bioactive constituents in crude extract were analyzed through using RP UHPLC-MS by adopting the method of [28] . In brief, UHPLC of Agilent 1290 Infinity liquid chromatography system coupled to Agilent 6520 AccurateMass Q-TOF mass spectrometer with dual ESI source was used. Column used in this experiment was Agilent Zorbax Eclipse XDB-C18, narrow-bore 2.1×150 mm, $3.5 \mu \mathrm{m}\left(\mathrm{P} / \mathrm{N}\right.$ : 930990-902). The Column was kept at $25^{\circ} \mathrm{C}$ while $4^{\circ} \mathrm{C}$ was set for auto-sampler. Flow rate was maintained at $0.5 \mathrm{ml} / \mathrm{min}$ and sample was injected as 1.0 $\mu \mathrm{L}$. $0.1 \%$ formic acid in water (A), $0.1 \%$ formic acid in acetonitrile (B) were used as mobile phase. Sample was run for $25 \mathrm{~min}$ and an extra of $5 \mathrm{~min}$ were given. Full scan mass spectrometry analysis was conducted on $\mathrm{m} / \mathrm{z}$ 100-1000 employing electro-spray ion source in negative fashion. Whereas, obtained results were processed with Agilent Mass Hunter Qualitative Analysis B.05.00 (Metabolomics-2017- 00004.m). Search Database:

METLIN_AM_PCDL-Ne 170502.cdb, with parameters as: Match tolerance: $5 \mathrm{ppm}$, Positive lons: $+\mathrm{H},+\mathrm{Na},+\mathrm{NH} 4$, Negative lons: $\mathrm{H}$. was used to identify the compounds.

\section{Statistical analysis}

Data obtained from all experiments in current study was expressed as means \pm S.E.M. For estimating the statistical significance, data was analyzed using, one way or two way analysis of variance (ANOVA) followed by an appropriate posttest either Dunnet or Bonfferoni. All statistical analysis were performed and graphs drawn using GraphPad Prism version 5.0 and 6.0 for windows (GraphPad Software, San Diego, CA, USA). The results showing a probability of $<0.05$ were considered as statistically significant.

\section{Results}

\section{Anti-hyperlipidemic effect of Salvia bucharica against lipofundin induced dyslipidemia}

\section{Effect on lipid profile}

Aqueous methanol extract of $S$. bucharica showed dose dependent antihyperlipedimc effect. Lipofundin administered to all group except normal control caused significant rise in lipid parameters. LIPO group at $8^{\text {th }}$ day produced significant increase in TC $(86.6 \pm 4.40 \mathrm{mg} / \mathrm{dL})$ and TG $(118 \pm 7.26 \mathrm{mg} / \mathrm{dL})$ as compared to normal control $(65 \pm 2.8,72.66 \pm 4.33 \mathrm{mg} / \mathrm{dL})$ with level of significance $\mathrm{P}<0.001$. LIPO group at $23^{\text {rd }}$ day also showed significant rise in serum total cholesterol $(84.33 \pm 4.25 \mathrm{mg} / \mathrm{dL})$ and serum triglyceride $(112 \pm 6.24$ $\mathrm{mg} / \mathrm{dL}$ ) in comparison of normal control with level of significance $\mathrm{p}<0.001$ and $p<0.01$ respectively. Atorvastatin $(10 \mathrm{mg} / \mathrm{kg})$ and $S$. bucharica at dose of $500 \mathrm{mg} / \mathrm{kg}$ caused remarkable $(\mathrm{p}<0.001)$ reduction in TC and TG level and showed comparable results. Atorvastatin and $S$. bucharica reduced TC to $61 \pm 4.94 \mathrm{mg} / \mathrm{dL}$ 
and $62.66 \pm 3.71 \mathrm{mg} / \mathrm{dL}$ respectively than LIPO $23^{\text {rd }}$ day. Atorvastatin and S. bucharica reduced serum TG to $72.66 \pm 4.33 \mathrm{mg} / \mathrm{dL}$ and $82.66 \pm 5.81 \mathrm{mg} / \mathrm{dL}$ respectively than LIPO $23^{\text {rd }}$ day. Both of these groups also showed significant reduction of LDL i.e $11.33 \pm 2.02 \mathrm{mg} / \mathrm{dL}$ and $10.46 \pm 1.84 \mathrm{mg} / \mathrm{dL}$ respectively than the LIPO $23^{\text {rd }}$ day $(32 \pm 2 \mathrm{mg} / \mathrm{dL}$ ) with level of significance $p<0.01$. SB also caused reduction in HDL and VLDL levels but the effect of extract on these parameters was not significant (Fig.1).

Effect on the atherogenic index (Al) and coronary risk index (CRI)

Aqueous methanol extract of $S$. bucharica showed dose dependent effect on Al and CRI. Atorvastatin (10 $\mathrm{mg} / \mathrm{kg}$ ) and aqueous methanol extract of $S$. bucharica at dose of $500 \mathrm{mg} / \mathrm{kg}$ showed significant reduction in Al to $0.73 \pm 0.06$ and $0.75 \pm 0.05$ respectively in comparison of LIPO $23^{\text {rd }}$ day $(1.63 \pm 0.15)$ with level of significance $p<0.01$. In case of $\mathrm{CRI}$, Atorvastatin $(10 \mathrm{mg} / \mathrm{kg})$ and aqueous methanol extract of $S$. bucharica at dose of $500 \mathrm{mg} / \mathrm{kg}$ showed significant reduction in CRI to $(1.73 \pm 0.06$ and $1.75 \pm 0.05)$ than the LIPO $23^{\text {rd }}$ day $(2.30 \pm 0.46)$ with level of significance $p<0.05$ (Fig.2).

\section{Effect of Salvia bucharica as antihyperlipidemic agent against Fructose treated rats}

\section{Effect on lipid profile}

Aqueous methanol extract of Salvia bucharica showed significant dose dependent antihyperlipedimc effect in fructose induce hyperlipidemia. Fructose group produced significant increase in total cholesterol (106.66 \pm $6.76 \mathrm{mg} / \mathrm{dL})$ and triglyceride $(196.66 \pm 7.26 \mathrm{mg} / \mathrm{dL})$ as compared to normal group (71 $\pm 2.30,91.66 \pm 6.00$ $\mathrm{mg} / \mathrm{dL}$ ) with level of significance $\mathrm{P}<0.001$. The Fructose + SB 250 and Fructose + SB 500 showed significant reduction in total cholesterol to $91 \pm 4.61 \mathrm{mg} / \mathrm{dL}$ and $82 \pm 3.75 \mathrm{mg} / \mathrm{dL}$ respectively than Fructose group with level of significance $\mathrm{p}<0.05$ and $\mathrm{P}<0.001$ respectively. The Fructose $+\mathrm{SB} 250$ and Fructose + SB 500 also showed significant reduction in triglycerides to $131.66 \pm 5.36 \mathrm{mg} / \mathrm{dL}$ and $81 \pm 6.24 \mathrm{mg} / \mathrm{dL}$ respectively than Fructose group with level of significance $p<0.05$ and $P<0.001$ respectively. Fructose + ATOR and Fructose + SB500 also caused significant reduction of VLDL level to $14.53 \pm 0.86 \mathrm{mg} / \mathrm{dL}$ and $17 \pm 0.57 \mathrm{mg} / \mathrm{dL}$ respectively in comparison of Fructose group (39.33 \pm 1.45$)$ with level of significance $p<0.001$ and $p<0.01$ respectively (Fig.3).

\section{Effect on atherogenic index (Al) and coronary risk index (CRI)}

Aqueous methanol extract of Salvia bucharica showed dose dependent effect on atherogenic index and coronary risk index in fructose induced hyperlipidemic rats. Atorvastatin $(10 \mathrm{mg} / \mathrm{kg})$ and aqueous methanol extract of Salvia bucharica at dose of $500 \mathrm{mg} / \mathrm{kg}$ showed significant reduction in Al to $0.93 \pm 0.14$ and $0.62 \pm$ 0.08 respectively than Fructose treated group $(1.43 \pm 0.12)$ with level of significance $p<0.01$ and $p<0.001$ respectively. In case of CRI, Atorvastatin $(10 \mathrm{mg} / \mathrm{kg})$ and aqueous methanol extract of Salvia bucharica at dose of $500 \mathrm{mg} / \mathrm{kg}$ showed significant reduction in CRI to $1.93 \pm 0.14$ and $1.62 \pm 0.08$ in comparison to Fructose group $(2.43 \pm 0.12)$ with level of significance $p<0.01$ and $p<0.001$ respectively (Fig.4).

\section{Beneficial potential of Salvia bucharica against fructose induced vascular dysfunction}


Salvia bucharica aqueous methanol extract showed effective improvement in endothelial dysfunction induced by fructose in dose dependent manner. In fructose treated rats, fructose caused vascular endothelium damage as shown by reduction in endothelium dependent vasorelaxation of aorta rings by acetylcholine after phenylephrine induced contraction. While Atorvastatin group and Salvia bucharica $500 \mathrm{mg} / \mathrm{kg}$ group protected the vascular endothelium damage and significant vasorelaxation was observed by acetylcholine as compared to fructose control group in dose dependent manner with level of significance $p<0.001$. Salvia bucharica 250 $\mathrm{mg} / \mathrm{kg}$ group do not show remarkable relaxation at lower doses but at dose of $10^{-5} \mathrm{~mol} / \mathrm{L}$ of acetylcholine, it showed significance relaxation with $\mathrm{p}$ value of 0.01 (Fig.5).

\section{Effect of Salvia bucharica on liver histopathology}

The histopathology of liver section of normal rats showed normal cell structure while the liver section of fructose fed rats showed the presence of destructive alteration and extensive fatty changes characterized by focal necrosis and damaged sinusoidal spaces and narrowing of central vein. The liver section of rats treated with Salvia bucharica at dose of $250 \mathrm{mg} / \mathrm{kg}$ showed less effect on necrosis, central vein damage and fatty changes. While Salvia bucharica at dose of $500 \mathrm{mg} / \mathrm{kg}$ and atorvastatin at dose of $10 \mathrm{mg} / \mathrm{kg}$ showed hepatoprotective activity in rats and histopathological changes significantly attenuated by these groups (Fig.6)

\section{Toxicity profile}

\section{Acute toxicity study and determination of $\mathrm{LD}_{50}$}

At graded doses, from $250 \mathrm{mg} / \mathrm{kg}$ up to $5000 \mathrm{mg} / \mathrm{kg}$ body weight of aqueous Methanol extract of Salvia bucharica did not show any sign of adverse reactions and no changes in animals up to $24 \mathrm{~h}$ after the administration of the extract to mice. $L_{50}$ value of aqueous Methanol extract of Salvia bucharica was found to be greater than $5000 \mathrm{mg} / \mathrm{kg}$.

\section{Sub-acute Toxicity Test}

No significant difference in body weight, and weight of liver, heart and kidney was observed between the control and extract-administered groups after 14 days in sub-acute study. In addition, no mortality was recorded throughout the period of observation. There was the decrease in level of serum ALT (U/L) and AST $(\mathrm{U} / \mathrm{L})$ but the creatinine $(\mathrm{mg} / \mathrm{dL})$ and urea $(\mathrm{mg} / \mathrm{dL})$ levels were comparable to normal control (Table 1$)$. 


\begin{tabular}{|lll|}
\hline Parameters & Normal & Treated \\
\hline Body weight $(\mathbf{g})$ & $33.75 \pm 3.25$ & $32 \pm 4$ \\
\hline Heart weight $\mathbf{( g )}$ & $0.16 \pm 0.02$ & $0.21 \pm 0.02$ \\
\hline Liver weight $(\mathbf{g})$ & $1.78 \pm 0.15$ & $1.64 \pm 0.03$ \\
\hline Kidney weight(g) & $0.47 \pm 0.07$ & $0.54 \pm 0.03$ \\
\hline Urea (mg/dL) & $22 \pm 02$ & $14.5 \pm 0.5$ \\
\hline Creatinine(mg/dL) & $0.7 \pm 0.1$ & $0.6 \pm 0.1$ \\
\hline ALT (U/L) & $175 \pm 05$ & $79 * \star \pm 10$ \\
\hline AST (U/L) & $157.5 \pm 2.5$ & $116.5 \pm 9.5$ \\
\hline
\end{tabular}

Table 1

Subacute toxicity study of Salvia bucharica

Values are expressed as mean \pm SEM. Statistical analysis was performed by using 2 way ANOVA. $* *=p<0.01$ (compared with normal group) 


\begin{tabular}{|c|c|c|c|c|c|c|c|}
\hline S.NO & RT & $\mathrm{m} / \mathrm{z}$ & Height & Proposed compound & Formula & $\begin{array}{l}\text { Molecular } \\
\text { mass }\end{array}$ & Volume \\
\hline 1 & 0.624 & 317.0605 & 9419 & Pyriftalid & $\begin{array}{l}\text { C15 } \\
\text { H14 N2 } \\
\text { O4 S }\end{array}$ & 318.0685 & 41722 \\
\hline 2 & 0.631 & 215.0353 & 178161 & Isobergaptene & $\begin{array}{l}\mathrm{C} 12 \mathrm{H} 8 \\
\mathrm{O} 4\end{array}$ & 216.0415 & 601787 \\
\hline 3 & 0.635 & 195.0528 & 41041 & 1,9-Dimethyluric acid & $\begin{array}{l}\mathrm{C} 7 \mathrm{H} 8 \\
\mathrm{~N} 4 \mathrm{O} 3\end{array}$ & 196.0601 & 140304 \\
\hline 4 & 0.636 & 259.0154 & 6965 & (E)-C-HDMAPP & $\begin{array}{l}\mathrm{C} 6 \mathrm{H} 14 \\
\text { 07 P2 }\end{array}$ & 260.0213 & 27630 \\
\hline 5 & 0.637 & 165.0418 & 24523 & 1-Methylxanthine & $\begin{array}{l}\mathrm{C} 6 \mathrm{H} 6 \\
\mathrm{~N} 4 \mathrm{O} 2\end{array}$ & 166.049 & 80893 \\
\hline 6 & 0.637 & 539.1489 & 13865 & $\begin{array}{l}\mathrm{N}, \mathrm{N}^{\prime}-\mathrm{Bis}(\mathrm{g}-\text { glutamyl)-3,3'- } \\
(1,2- \\
\text { propylenedithio)dialanine }\end{array}$ & $\begin{array}{l}\text { C19 } \\
\text { H32 N4 } \\
\text { O10 S2 }\end{array}$ & 540.1564 & 76070 \\
\hline 7 & 0.642 & 353.0956 & 8684 & ST638 & $\begin{array}{l}\text { C19 } \\
\text { H18 N2 } \\
\text { O3 S }\end{array}$ & 354.1019 & 68786 \\
\hline 8 & 0.644 & 135.0306 & 19328 & Hypoxanthine & $\begin{array}{l}\mathrm{C} 5 \mathrm{H} 4 \\
\mathrm{~N} 4 \mathrm{O}\end{array}$ & 136.038 & 66414 \\
\hline 9 & 0.651 & 179.061 & 64093 & 1,10-Phenanthroline & $\begin{array}{l}\mathrm{C} 12 \mathrm{H} 8 \\
\mathrm{~N} 2\end{array}$ & 180.0683 & 310019 \\
\hline 10 & 0.664 & 162.0784 & 25426 & 6-Dimethylaminopurine & $\begin{array}{l}\text { C7 H9 } \\
\text { N5 }\end{array}$ & 163.0851 & 135796 \\
\hline 11 & 0.664 & 191.055 & 7493 & $\mathrm{BEC}$ & $\begin{array}{l}\text { C5 H12 } \\
\text { B N O4 } \\
\text { S }\end{array}$ & 192.0627 & 31962 \\
\hline 12 & 0.665 & 387.1209 & 5761 & Abu-TyrMe-OH & $\begin{array}{l}\mathrm{C} 19 \\
\mathrm{H} 20 \mathrm{~N} 2 \\
\mathrm{O} 7\end{array}$ & 388.1285 & 40713 \\
\hline 13 & 0.669 & 397.1204 & 5093 & Cys Asn Tyr & $\begin{array}{l}\mathrm{C} 16 \\
\mathrm{H} 22 \mathrm{~N} 4 \\
\mathrm{O} 6 \mathrm{~S}\end{array}$ & 398.126 & 21530 \\
\hline 14 & 0.672 & 209.0681 & 15863 & 1,3,7-Trimethyluric acid & $\begin{array}{l}\mathrm{C} 8 \mathrm{H} 10 \\
\mathrm{~N} 4 \mathrm{O} 3\end{array}$ & 210.0747 & 70857 \\
\hline 15 & 0.673 & 105.0194 & 12779 & Glyceric acid & $\begin{array}{l}\text { C3 H6 } \\
\text { O4 }\end{array}$ & 106.0267 & 55835 \\
\hline 16 & 0.681 & 339.101 & 49686 & Arteglasin A & $\begin{array}{l}\mathrm{C} 17 \\
\mathrm{H} 2005\end{array}$ & 304.1328 & 223744 \\
\hline 17 & 0.683 & 125.0011 & 11752 & Dimethyl phosphate & $\begin{array}{l}\mathrm{C} 2 \mathrm{H} 7 \\
04 \mathrm{P}\end{array}$ & 126.0085 & 55970 \\
\hline 18 & 0.69 & 281.0925 & 15635 & Saphenic acid methyl & $\mathrm{C} 16$ & 282.0988 & 60085 \\
\hline
\end{tabular}




\begin{tabular}{|c|c|c|c|c|c|c|c|}
\hline & & & & ester & $\begin{array}{l}\mathrm{H} 14 \mathrm{~N} 2 \\
\text { O3 }\end{array}$ & & \\
\hline 19 & 0.726 & 133.0153 & 99638 & $\begin{array}{l}\text { 3,3-Dimethyl-1,2- } \\
\text { dithiolane }\end{array}$ & $\begin{array}{l}\mathrm{C} 5 \mathrm{H} 10 \\
\mathrm{~S} 2\end{array}$ & 134.0227 & 537518 \\
\hline 20 & 0.773 & 253.0955 & 5190 & Dyphylline & $\begin{array}{l}\text { C10 } \\
\text { H14 N4 } \\
\text { O4 }\end{array}$ & 254.1024 & 29745 \\
\hline 21 & 0.918 & 128.0356 & 76089 & N-Acryloylglycine & $\begin{array}{l}\text { C5 } \mathrm{H} 7 \mathrm{~N} \\
\text { O3 }\end{array}$ & 129.043 & 304158 \\
\hline 22 & 0.918 & 253.0939 & 34414 & Dyphylline & $\begin{array}{l}\text { C10 } \\
\text { H14 N4 } \\
\text { O4 }\end{array}$ & 254.1012 & 183670 \\
\hline 23 & 0.947 & 306.0607 & 7035 & Narciclasine & $\begin{array}{l}\text { C14 } \\
\text { H13 N } \\
07\end{array}$ & 307.0681 & 34367 \\
\hline 24 & 1.088 & 117.0193 & 25487 & Erythrono-1,4-lactone & $\begin{array}{l}\mathrm{C} 4 \mathrm{H} 6 \\
\mathrm{O} 4\end{array}$ & 118.0266 & 123693 \\
\hline 25 & 1.174 & 161.0461 & 6892 & Levoglucosan & $\begin{array}{l}\mathrm{C} 6 \mathrm{H} 10 \\
\mathrm{O} 5\end{array}$ & 162.0537 & 39568 \\
\hline 26 & 8.088 & 361.0983 & 15790 & Asp Asp Asn & $\begin{array}{l}\text { C12 } \\
\text { H18 N4 } \\
\text { O9 }\end{array}$ & 362.1058 & 92942 \\
\hline 27 & 8.257 & 225.1139 & 8737 & $\begin{array}{l}\text { Pyridine-2-azo-p- } \\
\text { dimethylaniline }\end{array}$ & $\begin{array}{l}\text { C13 } \\
\text { H14 N4 }\end{array}$ & 226.1213 & 69143 \\
\hline 28 & 8.341 & 186.1137 & 13375 & KAPA & $\begin{array}{l}\mathrm{C} 9 \mathrm{H} 17 \\
\mathrm{~N} O 3\end{array}$ & 187.121 & 172528 \\
\hline 29 & 9.007 & 265.0599 & 13514 & $\begin{array}{l}\text { 7-Acetoxy-7,8- } \\
\text { dihydroiodovulone I }\end{array}$ & $\begin{array}{l}\text { C23 } \\
\text { H33 I } \\
\text { O6 }\end{array}$ & 532.133 & 161454 \\
\hline 30 & 9.041 & 393.0876 & 17206 & Met-His-OH & $\begin{array}{l}\text { C16 } \\
\text { H18 N4 } \\
\text { O6 S }\end{array}$ & 394.0952 & 110163 \\
\hline 31 & 9.528 & 187.098 & 21206 & Nonic Acid & $\begin{array}{l}\mathrm{C} 9 \mathrm{H} 16 \\
\mathrm{O} 4\end{array}$ & 188.1053 & 157743 \\
\hline 32 & 9.577 & 269.1042 & 18700 & $\begin{array}{l}\text { Idebenone Metabolite } \\
\text { (Benzenebutanoic acid, } \\
\text { 2,5-dihydroxy-3,4- } \\
\text { dimethoxy-6-methyl-) }\end{array}$ & $\begin{array}{l}\text { C13 } \\
\text { H18 O6 }\end{array}$ & 270.1115 & 213324 \\
\hline 33 & 10.209 & 375.1227 & 5742 & 5-0-Methylchamanetin & $\begin{array}{l}\mathrm{C} 23 \\
\mathrm{H} 20 \mathrm{O} 5\end{array}$ & 376.1301 & 34356 \\
\hline 34 & 10.437 & 221.1193 & 5279 & (6S)-dehydrovomifoliol & $\begin{array}{l}\mathrm{C} 13 \\
\mathrm{H} 1803\end{array}$ & 222.1265 & 37628 \\
\hline 35 & 10.964 & 809.4353 & 7486 & Lucyoside J & $\begin{array}{l}\text { C42 } \\
\text { H66 } \\
015\end{array}$ & 810.443 & 63612 \\
\hline
\end{tabular}




\begin{tabular}{|c|c|c|c|c|c|c|c|}
\hline 36 & 11.037 & 327.2194 & 7061 & $\begin{array}{l}\text { 11-hydroperoxy-12,13- } \\
\text { epoxy-9-octadecenoic } \\
\text { acid }\end{array}$ & $\begin{array}{l}\text { C18 } \\
\text { H32 } 05\end{array}$ & 328.2266 & 60013 \\
\hline 37 & 11.422 & 1087.5373 & 8231 & Araloside C & $\begin{array}{l}\text { C53 } \\
\text { H84 } \\
\text { O23 }\end{array}$ & 1088.5447 & 78353 \\
\hline 38 & 11.424 & 566.2674 & 12848 & Calendasaponin C & $\begin{array}{l}\mathrm{C} 54 \\
\mathrm{H} 86 \\
\mathrm{O} 25\end{array}$ & 1134.5501 & 123199 \\
\hline 39 & 11.431 & 329.2336 & 13903 & $\begin{array}{l}\text { 5,8,12-trihydroxy-9- } \\
\text { octadecenoic acid }\end{array}$ & $\begin{array}{l}\text { C18 } \\
\text { H34 } 05\end{array}$ & 330.241 & 108743 \\
\hline 40 & 12.325 & 267.126 & 5617 & DMABA-d6 NHS ester & $\begin{array}{l}\text { C13 H8 } \\
\text { D6 N2 } \\
\text { O4 }\end{array}$ & 268.1334 & 36836 \\
\hline 41 & 12.877 & 647.3939 & 5339 & $\begin{array}{l}\text { 3alpha-O-trans-Feruloyl- } \\
\text { 2alpha-hydroxy-12-ursen- } \\
\text { 28-oic acid }\end{array}$ & $\begin{array}{l}\mathrm{C} 40 \\
\mathrm{H} 56 \mathrm{O}\end{array}$ & 648.4008 & 47391 \\
\hline 42 & 13.145 & 293.1786 & 48842 & Tetradecyl sulfate & $\begin{array}{l}\mathrm{C} 14 \\
\mathrm{H} 3004 \\
\mathrm{~S}\end{array}$ & 294.186 & 395783 \\
\hline 43 & 13.22 & 207.1398 & 15514 & $\begin{array}{l}\text { (5alpha,8beta,9beta)-5,9- } \\
\text { Epoxy-3,6- } \\
\text { megastigmadien-8-ol }\end{array}$ & $\begin{array}{l}\mathrm{C} 13 \\
\mathrm{H} 20 \mathrm{O} 2\end{array}$ & 208.1471 & 190675 \\
\hline 44 & 13.43 & 293.1778 & 6925 & Tetradecyl sulfate & $\begin{array}{l}\mathrm{C} 14 \\
\mathrm{H} 30 \mathrm{O} \\
\mathrm{S}\end{array}$ & 294.185 & 51767 \\
\hline 45 & 13.459 & 309.1706 & 35949 & $\begin{array}{l}\text { methyl 8-[2-(2-formyl- } \\
\text { vinyl)-3-hydroxy-5-oxo- } \\
\text { cyclopentyl]-octanoate }\end{array}$ & $\begin{array}{l}\text { C17 } \\
\text { H26 } 05\end{array}$ & 310.178 & 350994 \\
\hline 46 & 14.026 & 293.1803 & 13269 & Tetradecyl sulfate & $\begin{array}{l}\mathrm{C} 14 \\
\mathrm{H} 30 \mathrm{O}\end{array}$ & 294.1876 & 108467 \\
\hline 47 & 14.183 & 194.0827 & 5814 & O-Benzyl-L-Serine & $\begin{array}{l}\text { C10 } \\
\text { H13 N } \\
\text { O3 }\end{array}$ & 195.09 & 41932 \\
\hline 48 & 16.628 & 555.2942 & 40000 & $\mathrm{PI}(\mathrm{P}-16: 0 / 0: 0)$ & $\begin{array}{l}\mathrm{C} 25 \\
\mathrm{H} 49 \\
011 \mathrm{P}\end{array}$ & 556.301 & 631571 \\
\hline 49 & 19.329 & 381.2357 & 5805 & STS-135 & $\begin{array}{l}\mathrm{C} 24 \\
\mathrm{H} 31 \mathrm{~F} \\
\mathrm{~N} 2 \mathrm{O}\end{array}$ & 382.2428 & 69167 \\
\hline
\end{tabular}

Table 2

List of compounds identified by LC-MS analysis of DB-Cr

Assessment of anti-oxidant activity 


\section{Free radical scavenging activity of Salvia bucharica against DPPH (1,1-Diphenyl-2-picryl hydrazyl)}

Aqueous methanol extract of Salvia bucharica showed remarkable concentration dependent DPPH scavenging activity. The results were more profound than standard (Ascorbic acid) at almost all the concentration except $100 \mathrm{ug} / \mathrm{mL}$. At $100 \mathrm{ug} / \mathrm{mL}$ the plant showed comparable result with ascorbic acid having values of $98.62 \pm$ 0.01 and $98.61 \pm 0.01$ respectively.

\section{Phytochemical analysis of aqueous methanol extract of Salvia bucharica using LC-MS}

LC-MS analysis of aqueous methanol extract of Salvia bucharica revealed the presence of several compounds of which 49 were identified. The major compounds found in chemical analysis of Salvia bucharica were belonging to flavonoid, phenol, alkaloids and tannins class. As shown in figure Methyl xanthine, glyceric acid, nonic acid, octadecenoic acid, araloside and tri methyluric acid were commonly identified in aqueous methanol extract of Salvia bucharica.

\section{Discussion}

Lipofundin is a fat emulsion which is used as an energy source in parentral nutrition, but experimental studies evidenced the development of atherosclerotic lesion, lipid peroxidation and oxidative stress in rabbits [29, 30]. In the present investigation, it was observed that lipofundin caused significant increase in total cholesterol and triglyceride level ( $86.6 \pm 4.40$ and $118.33 \pm 7.26 \mathrm{mg} / \mathrm{dL}$ respectively) in rabbits after intravenous administration for 8 days. In order to assess the possible effect of $S$. buchrica on lipid profile, aqueous methanol extract in doses of 250 and $500 \mathrm{mg} / \mathrm{kg}$ was administered in lipofundin treated hyperlipidemic rabbits. $500 \mathrm{mg} / \mathrm{kg}$ dose of extract produced significant $(p<0.001)$ reduction in level of triglycerides, total cholesterol and LDL as compared to lipofundin treated negative control group (Table 3.1, Fig.3.1). It is well known that elevated total cholesterol level plays major role in development of coronary artery diseases [31] and triglycerides play key role in regulation of lipoprotein interaction thus maintaining metabolism of lipids [32]; Hence, attenuation of these factors by extract may contribute to the possible antihyperlipidemic potential of Salvia bucharica which is in agreement with the previous findings [33]. Formerly, it has been established on the basis of clinical and animal studies that chronic administration of fructose contributes to the development of various abnormalities such as dyslipidemia, hypertension, insulin resistance, oxidative stress and decreased glucose utilization [34]. Present study demonstrated that administration of fructose $(25 \% \mathrm{w} / \mathrm{v})$ in drinking water for 28 days provoked marked increase $(p<0.001)$ in the level of TC, TG and VLDL, which is an indication of development of hyperlipidemia. Further, the results showed that fructose treatment also caused endothelium dysfunction in aorta of treated rats [35].

Subsequently administration of aqueous methanol extract of SB remarkably decreased the levels of lipid profile in serum of treated animals indicating antihyperlipidemic potential, however, the HDL-C level remains unaffected. This valuable effect might be related to enhanced activity of endothelium bound lipoprotein lipase which is involved in hydrolysis of triglycerides to fatty acids [36] or by inhibition of pancreatic lipase as previously, it has been reported that high fructose diet increases serum pancreatic lipase activity, which is involved in cleavage of dietary triglycerides and thus leads to digestion of lipids [16]. Therefore, inhibition of pancreatic lipase can cause reduction in fat absorption hence, cholesterol level in blood could be decreased. 
LC-MS analysis of $S$. bucharica evident the presence of arasolide, derivative of oleanolic acid, Somova and its colleagues [37] had established the antihyperlipidemic effect of olenolic acid therefore, it could be assumed that lipid lowering effect offered by $S$. bucharica may at least be partially linked to the presence of araloside. Further, Lipoic acid derivative, 3,3-Dimethyl-1,2-dithiolane, has been identified as an active constituent of $S$. bucharica and former reports [38] evinced the noticeable cholesterol lowering effect exerted by lipoic acid in rabbits, in addition dithiolane also improves the insulin sensitivity and reduced serum triglyceride level [39]. Therefore, it could be deduced that $S$. bucharica mediated antihyperlipidemic effect observed in present study may be due to the presence of these active principles. Cholestrol lowering effect exerted by $S$. bucharica could be attributed to the presence of saponins and methylxanthines as previous studies have demonstrated the hypocholestrolemic and lipid lowering properties of saponins [40] and methylxanthines [41].

Literature has shown that terpenes have potential to decrease the activity of HMG-COA reductase thus limiting the synthesis of cholesterol [42], as Salvadiol; a terpenoid is active constituent of $S$. bucharica [7]. Hence, the aforementioned findings suggest that antihyperlipidemic effect of extract might be linked with the presence of terpenes.

To provide the further basis for antihyperlipidemic effect of SB, vascular reactivity to various concentrations of acetylcholine $\left(10^{-9}-10^{-4} \mathrm{~mol} / \mathrm{L}\right)$ was studied in rat thoracic aorta. Aqueous methanol extract obtained from aerial parts of Salvia bucharica potentially prevented the loss of endothelium functional integrity that was significantly compromised in fructose treated rat thoracic aorta. As endothelial dysfunction endorses dyslipidemia, atherosclerosis and hypertension, so, in the light of present findings, it can therefore be deduced, that Salvia bucharica produced antihperlipidemic effect which might be attributed to multiple possible pathways including anticipation of endothelial dysfunction.

Additionally, it is popularly known that chronic administration of fructose culminates in fat deposition in hepatocytes and increased liver weight [43]. Hence, to evaluate the possible protective effect of Salvia bucharica, histopathological studies of liver tissues were performed. The result presented less alteration in hepatic vein and sinosidal spaces were examined in extract treated groups, when compared to fructose treated group reflecting protective role of Salvia bucharica on hepatocytes. Moreover, observation of hepatocytes clearly demonstrated that size of hepatocytes and central vein in Salvia bucharica treated rats was equivalent to normal rats and was also comparable to standard treated group.

It is evident from recorded results that atherogenic index (Al) and coronary risk index (CRI) was significantly ameliorated in both models (lipofundin and fructose induced hyperlipidemia) by treatment of aqueous methanol extract of Salvia bucharica. Atherogenic index being an important indicator of coronary risk is of great consideration [44].

Reactive oxygen species are involved in oxidation of low density lipoprotein, major contributor in endothelial dysfunction [5].The significant finding of present work is the antioxidant effect of $S$. bucharica. The results of DPPH radical scavenging assay predicted that $S$. bucharica showed more pronounced effect as compared to ascorbic acid (Fig 7). Hence, it could be proposed from aforementioned findings that antihyperlipidemic effect of Salvia bucharica might be attributed to the presence of terpenes and free radical scavenging potential of plant. 
To assess safety profile aqueous methanol extract of $S$. bucharica was administered in mice, findings of acute toxicity study evinced that $L_{50}$ of extract is above $5000 \mathrm{mg} / \mathrm{kg}$, which makes the extract a candidate of class 5 that is lowest toxic. Further results of subacute toxicity study showed no toxic effects thus referring the extract to be quite probably safe. Aqueous methanol extract obtained from aerial parts of Salvia bucharica M. Pop possesses antihyperlipidemic activity in the experimental animals at the dose of $500 \mathrm{mg} / \mathrm{kg}$. It significantly reduced lipid profile $(p<0.05)$ in the lipofundin and fructose induced hyperlipidemia. Furthermore, in fructose fed rats, studies on the isolated aorta showed the vascular protective activity and histopathological examination displayed that this extract has hepatoprotective potential. Toxicity studies demonstrated that this plant extract is safer upto $5000 \mathrm{mg} / \mathrm{kg}$ and no sign of morbidity shown. However the results are too much encouraging but further research work is required for scientific validation and to isolate the compound for further studies.

\section{Conclusion}

It is concluded that Salvia bucharica has shown dose dependent antihyperlipidemic activity .In addition, Studies performed on the isolated thoracic aorta and histolopathological studies on liver demonstrated that Salvia bucharica has endothelial dependent vasoprotective and hepatoprotective activity respectively as compared to fructose fed rats. Furthermore, the plant has been found to be safe in toxicity studies.

\section{Abbreviations}

Total cholesterol (TC), Triglyceride (TG), high density lipoprotein cholesterol (HDL-C) VLDL I, Low density lipoprotein (LDL-C), Atherogenic index (AI), Coronary risk index (CRI).

\section{Declaration}

\section{Ethics approval}

The experimental protocols were approved from Institutional Animal Ethics Committee, College of Pharmacy, University of Sargodha (Approval No. 43A24 IEC UOS).

\section{Informed Consent}

Not Applicable

\section{Funding}

Not Applicable

\section{Authors' contributions}

Alamgeer and Hafiz Muhammad Irfan designed this study and provide the necessary facilities for experiments. Muhammad Ishfaq Ahmad: Perform the experiments, Hira Asif Collect the results and write the article. Nasser Hadal Alotaibi, Khalid Saad Alharbi, Syed Nasir Abbas Bukhari performed phytochemical studies. 
and all other authors wrote and review the manuscript:

\section{Author details}

Not Applicable

\section{Competing interests}

The authors declare that they have no competing interests.

\section{Acknowledgment}

Not Applicable

\section{Availability of data and materials}

The data supporting findings of this study are available from the corresponding author upon request.

\section{Consent for publication}

All of authors consent to publication of this study in Journal of Chinese Medicine.

\section{References}

1. Mahamuni SP, Khose RD, Menaa F, Badole SL. Therapeutic approaches to drug targets in hyperlipidemia. BioMedicine 2012; 2(4):137-146.

2. Jani Dilip K. A Study of Anti-Hyperlipidemic Activity of Polyherbal Formulation Using Various Experimental Animal Models. Inventi Rapid: Ethnopharmacology 2011; 2(1):3.

3. Gaziano T, Reddy KS, Paccaud F, Horton S, Chaturvedi V. Cardiovascular disease. 2006.

4. Cai H, Harrison DG. Endothelial dysfunction in cardiovascular diseases: the role of oxidant stress. Circulation research 2000; 87(10):840-844.

5. Jamshed H, Gilani AH. Almonds Inhibit Dyslipidemia and Vascular Dysfunction in Rats through Multiple Pathways-3. The Journal of nutrition 2014; 144(11):1768-1774.

6. Ali I, Ahmed W, Tariq M, Asghar R, Hussain MA. Therapeutic potential of ethanolic extract of Solanum nigrum for lipofundin-induced hyperlipidemia in Rabbits. Pure and Applied Biology 2016; 5(1):85.

7. Ahmad VU, Zahid M, Ali MS, Jassbi AR, Abbas M, Ali Z, Iqbal MZ. Bucharioside and buchariol from Salvia bucharica. Phytochemistry 1999; 52(7):1319-1322.

8. Tareen RB, Bibi T, Khan MA, Ahmad M, Zafar M, Hina S. Indigenous knowledge of folk medicine by the women of Kalat and Khuzdar regions of Balochistan, Pakistan. Pak J Bot 2010; 42(3):1465-1485.

9. Ghayur MN, Gilani AH. Ginger lowers blood pressure through blockade of voltage-dependent calcium channels. Journal of cardiovascular pharmacology 2005; 45(1):74-80.

10. Titrikou S, Eklu-Gadegbeku K, Mouzou A, Aklikokou K, Gbeassor M. Calcium antagonistic activity of Biophytum petersianum on vascular smooth muscles of wistar rat. Iranian Journal of Pharmacology and Therapeutics 2007; 6(2):185-180. 
11. Clark LC, Combs GF, Turnbull BW, Slate EH, Chalker DK, Chow J, Davis LS, Glover RA, Graham GF, Gross EG. Effects of selenium supplementation for cancer prevention in patients with carcinoma of the skin: a randomized controlled trial. Jama 1996; 276(24):1957-1963.

12. Adeneye AA, Adeyemi OO, Agbaje EO. Anti-obesity and antihyperlipidaemic effect of Hunteria umbellata seed extract in experimental hyperlipidaemia. Journal of Ethnopharmacology 2010; 130(2):307-314.

13. Kanthe PS, Patil BS, Bagali S, Deshpande A, Shaikh GB, Aithala M. Atherogenic index as a predictor of cardiovascular risk among women with different grades of obesity. IJCRIMPH 2012; 4(10):1767-1774.

14. Ghuffar A, Ahmad T, Mushtaq MN. Antihyperlipidemic effect of Berberis orthobotrys in hyperlipidemic animal models. Bangladesh Journal of Pharmacology 2014; 9(3):377-382.

15. Dhingra D, Lamba D, Kumar R, Nath P, Gauttam S. Antihyperlipidemic activity of Aloe succotrina in rats: possibly mediated by inhibition of HMG-CoA reductase. ISRN pharmacology 2014; 2014.

16. Furchgott RF, Zawadzki JV. The obligatory role of endothelial cells in the relaxation of arterial smooth muscle by acetylcholine. nature 1980; 288(5789):373.

17. Ajay M, Chai H, Mustafa A, Gilani AH, Mustafa MR. Mechanisms of the anti-hypertensive effect of Hibiscus sabdariffa L. calyces. Journal of Ethnopharmacology 2007; 109(3):388-393.

18. Aziz N, Mehmood MH, Mandukhal SR, Bashir S, Raoof S, Gilani AH. Antihypertensive, antioxidant, antidyslipidemic and endothelial modulating activities of a polyherbal formulation (POL-10). Vascular pharmacology 2009; 50(1-2):57-64.

19. Chou C-L, Pang C-Y, Lee TJ, Fang T-C. Direct renin inhibitor prevents and ameliorates insulin resistance, aortic endothelial dysfunction and vascular remodeling in fructose-fed hypertensive rats. Hypertension Research 2013; 36(2):123.

20. Arsad S, Esa N, Hamzah H. Histopathologic changes in liver and kidney tissues from male Sprague Dawley rats treated with Rhaphidophora decursiva (Roxb.) schott extract. J Cytol Histol S 2014; 4(1):1-6.

21. Xia X, Ma Y, Xing X, Huang C, Li L, Gui G, Liu Q, Xue S. Antioxidant and hepatoprotective effect of different extracts of guizhencao (herba bidentis bipinnatae) against liver injury in hyperlipidemia rats. Journal of Traditional Chinese Medicine 2013; 33(4):518-523.

22. Guideline O. for the testing of chemicals, Guidance document on acute oral toxicity. Environmental health and safety monograph series on testing and assessment 2008:1-27.

23. Akhila JS, Shyamjith D, Alwar M. Acute toxicity studies and determination of median lethal dose. Current science 2007:917-920.

24. Adewale OB, Onasanya A, Anadozie SO, Abu MF, Akintan IA, Ogbole CJ, Olayide II, Afolabi OB, Jaiyesimi KF, Ajiboye BO. Evaluation of acute and subacute toxicity of aqueous extract of Crassocephalum rubens leaves in rats. Journal of ethnopharmacology 2016; 188:153-158.

25. Thanabhorn S, Jaijoy K, Thamaree S, Ingkaninan K, Panthong A. Acute and subacute toxicity study of the ethanol extract from Lonicera japonica Thunb. Journal of ethnopharmacology 2006; 107(3):370-373.

26. Miliauskas G, Venskutonis P, Van Beek T. Screening of radical scavenging activity of some medicinal and aromatic plant extracts. Food chemistry 2004; 85(2):231-237.

27. Dudonné S, Vitrac X, Coutiere P, Woillez M, Mérillon J-M. Comparative study of antioxidant properties and total phenolic content of 30 plant extracts of industrial interest using DPPH, ABTS, FRAP, SOD, and ORAC 
assays. Journal of agricultural and food chemistry 2009; 57(5):1768-1774.

28. Saleem H, Htar TT, Naidu R, Nawawi NS, Ahmad I, Ashraf M, Ahemad N. Biological, chemical and toxicological perspectives on aerial and roots of Filago germanica (L.) huds: Functional approaches for novel phyto-pharmaceuticals. Food and Chemical Toxicology 2019; 123:363-373.

29. Jellinek H, Hársing J, Füzesi S. A new model for arteriosclerosis an electron-microscopic study of the lesions induced by iv administered fat. Atherosclerosis 1982; 43(1):7-18.

30. Roche LD, Medina EA, Hernández-Matos Y, Viart MB, López AV, Fernández-Sánchez E. High levels of lipid peroxidation induced by Lipofundin administration correlate with atherosclerotic lesions in rabbits. Pharmacologyonline 2010; 3:727-736.

31. Huang H, Mai W, Liu D, Hao Y, Tao J, Dong Y. The oxidation ratio of LDL: a predictor for coronary artery disease. Disease markers 2008; 24(6):341-349.

32. Duraipandiyan V, AI-Dhabi NA, Irudayaraj SS, Sunil C. Hypolipidemic activity of friedelin isolated from Azima tetracantha in hyperlipidemic rats. Revista Brasileira de Farmacognosia 2016; 26(1):89-93.

33. Vembu S, Sivanasan D, Prasanna G. Effect of Phoenix dactylifera on high fat diet induced obesity. J Chem Pharm Res 2012; 4(1):348-352.

34. Maithilikarpagaselvi N, Sridhar MG, Swaminathan RP, Zachariah B. Curcumin prevents inflammatory response, oxidative stress and insulin resistance in high fructose fed male Wistar rats: Potential role of serine kinases. Chemico-biological interactions 2016; 244:187-194.

35. Stanhope KL, Schwarz J-M, Havel PJ. Adverse metabolic effects of dietary fructose: results from recent epidemiological, clinical, and mechanistic studies. Current opinion in lipidology 2013; 24(3):198.

36. Zouari R, Hamden K, El Feki A, Chaabouni K, Makni-Ayadi F, Kallel C, Sallemi F, Ellouze-Chaabouni S, Ghribi-Aydi D. Protective and curative effects of Bacillus subtilis SPB1 biosurfactant on high-fat-highfructose diet induced hyperlipidemia, hypertriglyceridemia and deterioration of liver function in rats. Biomedicine \& pharmacotherapy 2016; 84:323-329.

37. Somova L, Nadar A, Rammanan P, Shode F. Cardiovascular, antihyperlipidemic and antioxidant effects of oleanolic and ursolic acids in experimental hypertension. Phytomedicine 2003; 10(2-3):115-121.

38. Amom Z, Zakaria Z, Mohamed J, Azlan A, Bahari H, Baharuldin MTH, Moklas MA, Osman K, Asmawi Z, Hassan MKN. Lipid lowering effect of antioxidant alpha-lipoic Acid in experimental atherosclerosis. Journal of clinical biochemistry and nutrition 2008; 43(2):88-94.

39. Chittiboyina AG, Venkatraman MS, Mizuno CS, Desai PV, Patny A, Benson SC, Ho Cl, Kurtz TW, Pershadsingh HA, Avery MA. Design and synthesis of the first generation of dithiolane thiazolidinedioneand phenylacetic acid-based PPARy agonists. Journal of medicinal chemistry 2006; 49(14):4072-4084.

40. Marrelli M, Conforti F, Araniti F, Statti G. Effects of saponins on lipid metabolism: A review of potential health benefits in the treatment of obesity. Molecules 2016; 21(10):1404.

41. Mhd Jalil AM, Ismail A, Chong PP, Hamid M, Syed Kamaruddin SH. Effects of cocoa extract containing polyphenols and methylxanthines on biochemical parameters of obese-diabetic rats. Journal of the Science of Food and Agriculture 2009; 89(1):130-137.

42. Clegg R, Middleton B, Bell G, White D. The mechanism of cyclic monoterpene inhibition of hepatic 3hydroxy-3-methylglutaryl coenzyme A reductase in vivo in the rat. Journal of Biological Chemistry 1982; 
257(5):2294-2299.

43. Saba E, Jeon BR, Jeong D-H, Lee K, Goo Y-K, Kim S-H, Sung C-K, Roh S-S, Kim SD, Kim H-K. Black ginseng extract ameliorates hypercholesterolemia in rats. Journal of ginseng research 2016; 40(2):160-168.

44. Lakshmi B, Neelima N, Kasthuri N, Umarani V, Sudhakar M. Antihyperlipidemic activity of Bauhinia purpurea extracts in hypercholesterolemic albino rats. International journal of pharmtech research 2011; 3(3):1265-1272.

\section{Figures}

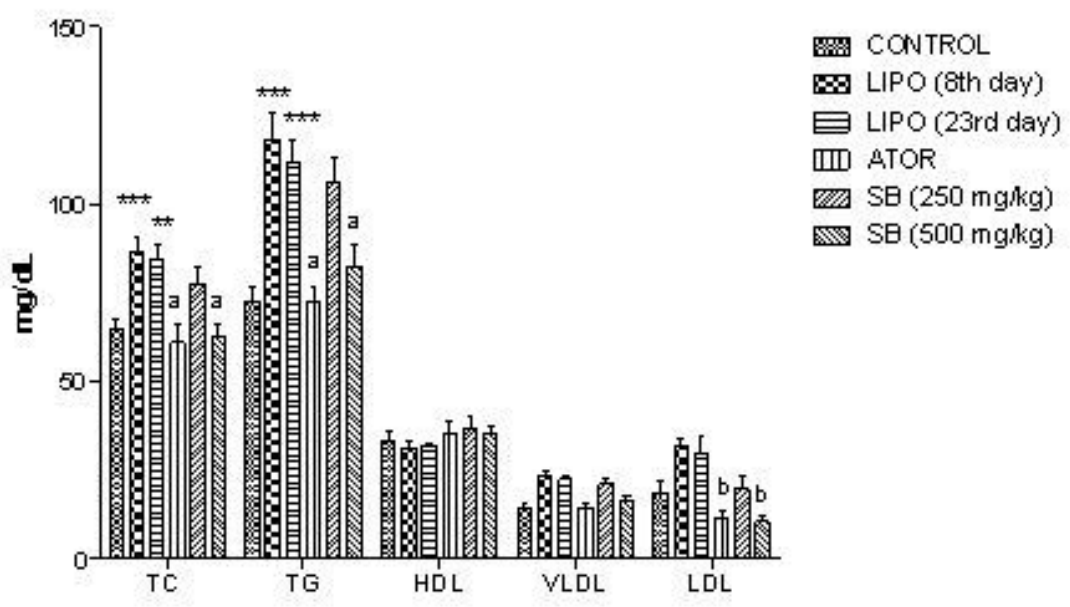

Figure 1

Attenuation in lipid profile by S. bucharica aqueous methanol extract. Values are represented as mean \pm SEM. Statistical analysis was performed using 2 way ANOVA. ${ }^{*}=p<0.05, * *=p<0.01, * \star *=p<0.001$ (when compared with CONTROL). $a=p<0.001, b=p<0.01$ (compared with lipofundin 23rd day control). LIPO= Lipofundin group, ATOR= atorvastatin treated group, SB= Salvia bucharica

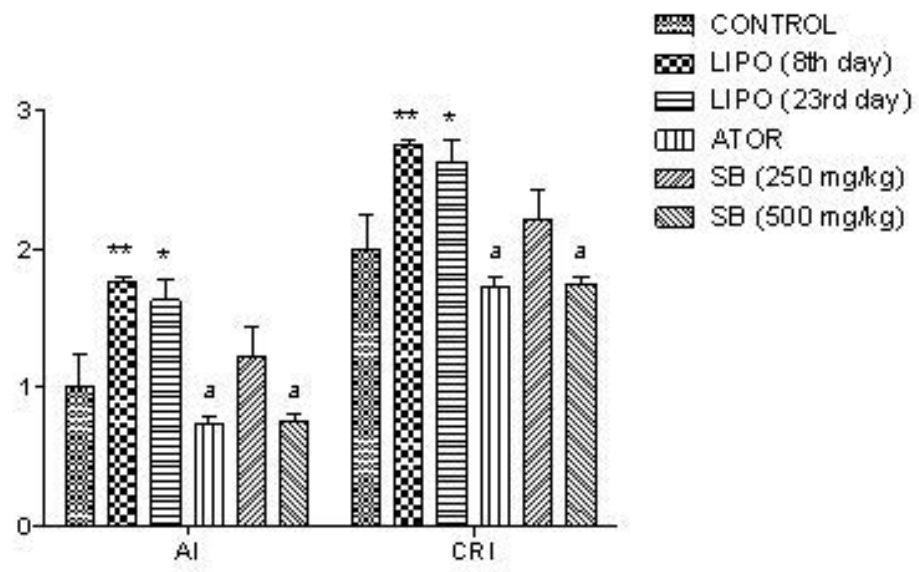


Figure 2

Attenuation in the atherogenic index (Al) and coronary risk index (CRI) by S. bucharica aqueous methanol extract. Values are expressed as mean \pm SEM. Where, ${ }^{*}=p<0.05,{ }^{* *}=p<0.01$ (compared with CONTROL). While, $a=p<0.001$ (compared with lipofundin 23rd day control). LIPO= Lipofundin group, ATOR= atorvastatin treated group, $\mathrm{SB}=$ Salvia bucharica

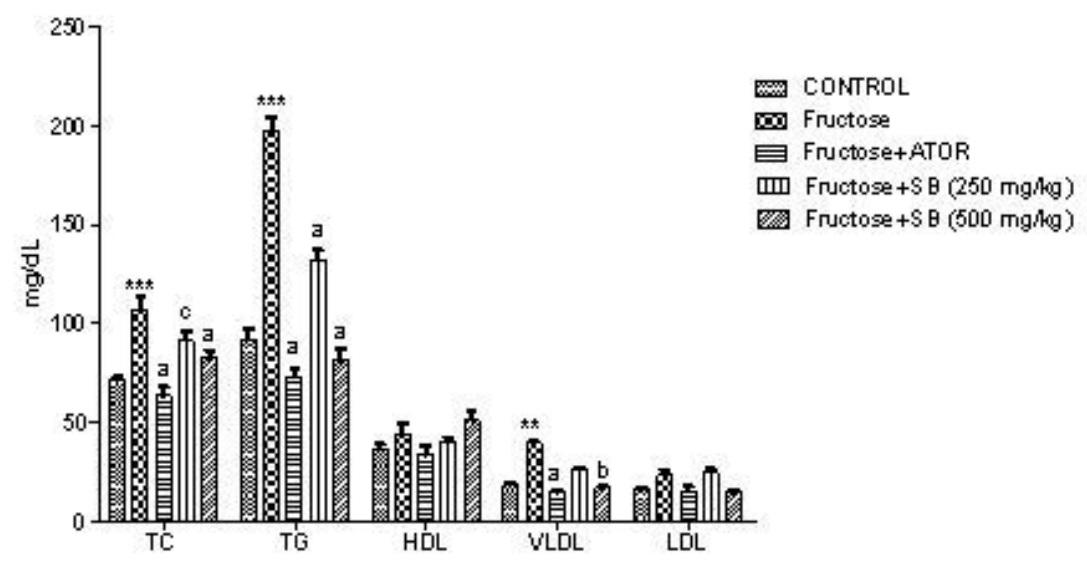

Figure 3

SB mediated changes in serum lipid profile in fructose induced hyperlipidemia. Data is depicted as mean \pm SEM. Statistical analysis was performed by using two way ANOVA. ${ }^{* *}=p<0.01, * \star *=p<0.001$ (compared with normal control). $a=p<0.001, b=p<0.01, c=p<0.05$ (compared with fructose control).

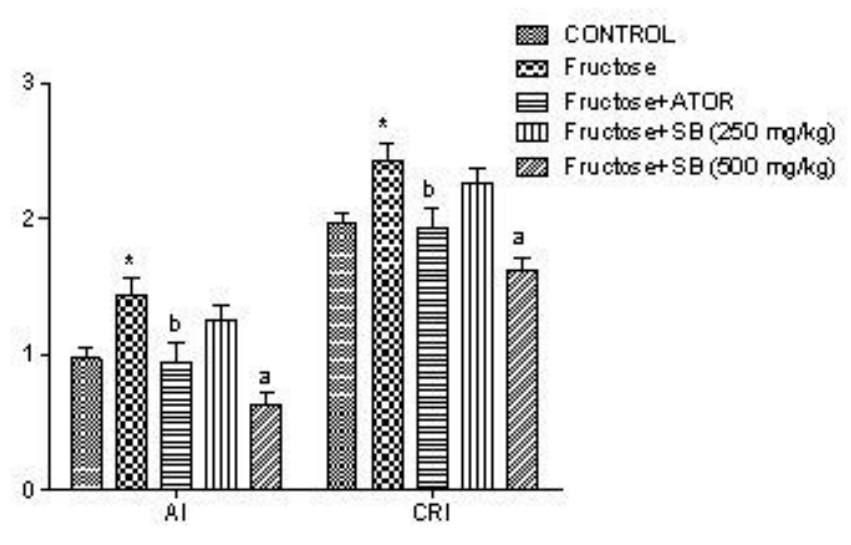

Figure 4

Attenuation in the atherogenic index (Al) and coronary risk index (CRI) by Salvia bucharica. Values are stated as mean $\pm \operatorname{SEM}(n=5)$. Where, ${ }^{*}=p<0.05$ (compared with normal control) and $a=p<0.001, b=p<0.01$ (compared with fructose control). 


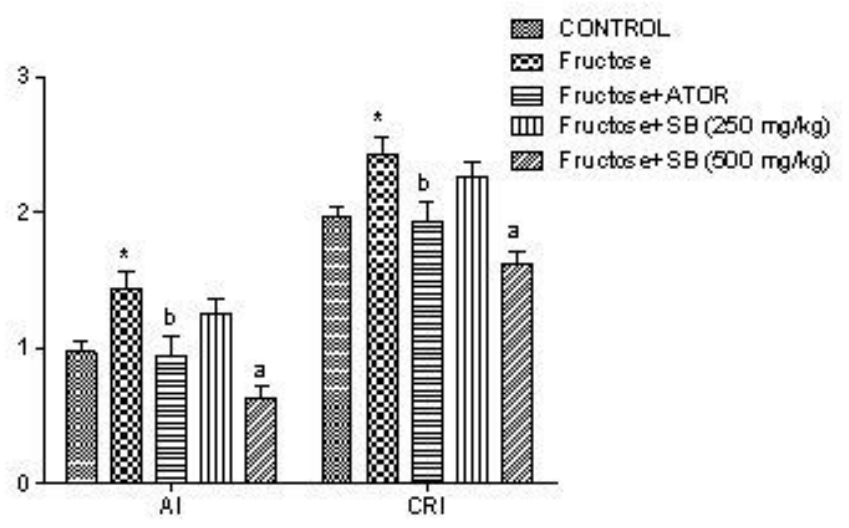

\section{Figure 5}

Protective effect of Salvia bucharica in vascular dysfunction induced by fructose. Values are depicted as mean $\pm \operatorname{SEM}(n=5)$. Where ${ }^{\star \star \star}=p<0.001$ (compared with normal), while $a=p<0.001, b=p<0.01, c=p<0.01$ (compared with negative control). $\mathrm{Al}=\mathrm{Atherogenic}$ index $\mathrm{CRI}=$ coronary risk index
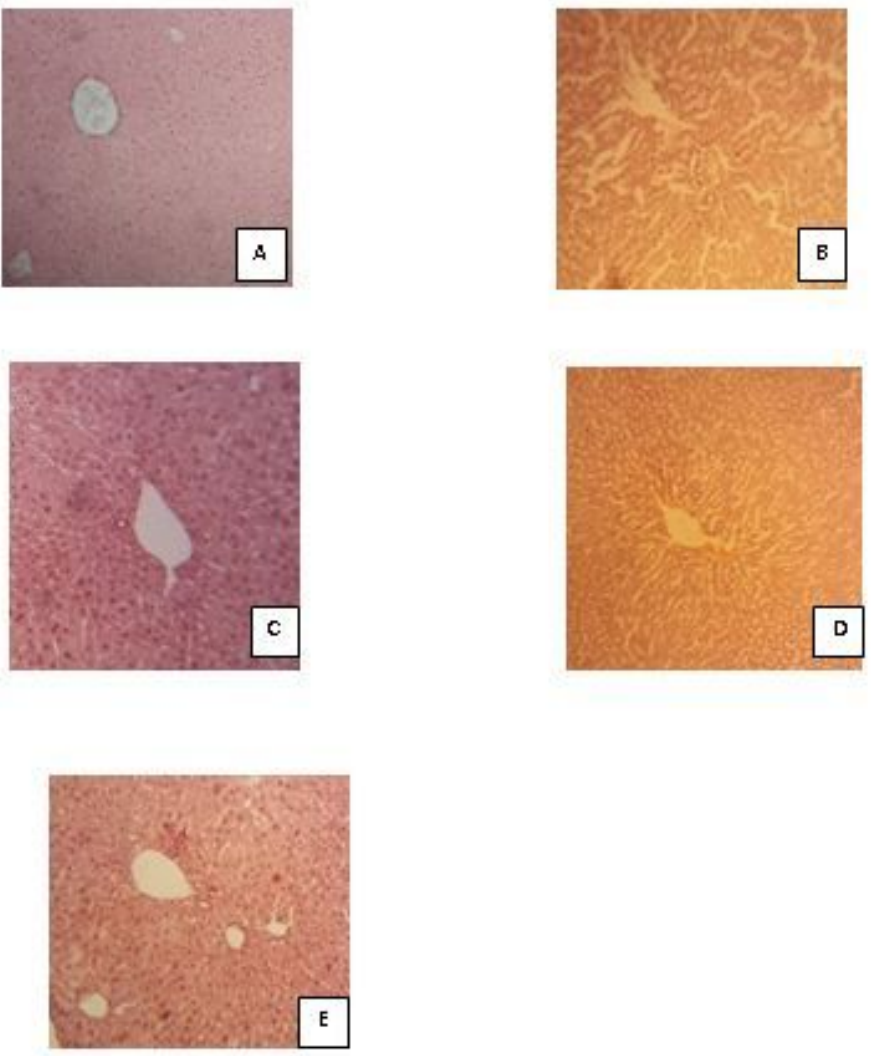

\section{Figure 6}

Effect of Salvia bucharica on liver histopathology. A: normal control group; B: fructose control group; C: standard group; D: SB $250 \mathrm{mg}$; E: SB $500 \mathrm{mg}$ 


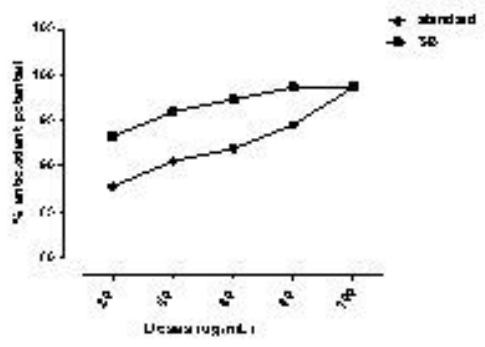

Figure 7

Free radical scavenging activity of Salvia bucharica against DPPH

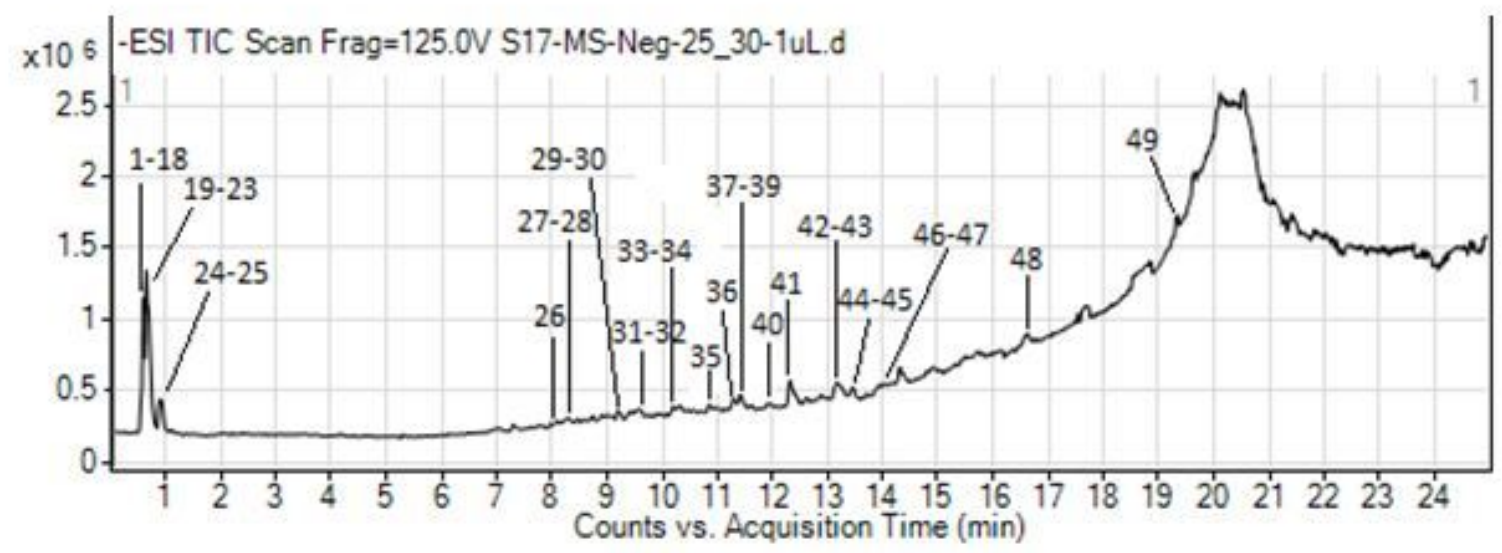

Figure 8

Illustrative figure of LC-MS analysis of Salvia Buchrica

\section{Supplementary Files}

This is a list of supplementary files associated with this preprint. Click to download.

- minimumstandardsofreportingcheklist.pdf 